\title{
Nortriptyline Hydrochloride
}

National Cancer Institute

\section{Source}

National Cancer Institute. Nortriptyline Hydrochloride. NCI Thesaurus. Code C704.

The hydrochloride salt form of nortriptyline, a tricyclic antidepressant agent used for short-term treatment of various forms of depression. Nortriptyline blocks the norepinephrine presynaptic receptors, thereby blocking the reuptake of this neurotransmitter and raising the concentration in the synaptic cleft in the CNS. Nortriptyline also binds to alpha-adrenergic, histaminergic and cholinergic receptors. Long-term treatment with nortriptyline produces a downregulation of adrenergic receptors due to the increased stimulation of these receptors. 